\title{
Weapons of Mass Destruction and Modern Terrorism: Implications for Global Security
}

\author{
O. Ike Okoro ${ }^{1} \&$ Nduka Lucas Oluka ${ }^{2}$ \\ ${ }^{1}$ Department of Intelligence and Security Studies, Novena University, Ogume, Delta State, Nigeria \\ ${ }^{2}$ Department of Political Science, Novena University Ogume, Delta State, Nigeria \\ Correspondence: O. Ikechukwu Okoro.E-mail: profiokoro@gmail.com
}

Received: September 25, 2018

Accepted: January 10, 2019

Online Published: February 28, 2019

doi:10.5539/ass.v15n3p1

URL: https://doi.org/10.5539/ass.v15n3p1

\begin{abstract}
The hazard of biological, chemical and nuclear materials, regarded as Weapons of Mass Destruction (WMD), intercalating the arsenal of terrorists is the biggest crime and challenge against humanity. Every such crime and challenge ought to be named appropriately; and state actors experiencing such owe it to their citizens to act speedily and with certainty against terrorists. Even with the on-going war on terrorism, there has been a surge in terrorist activities in some parts of the world. Terrorists in our contemporary age have also embraced startling trends in their operational mode since the 11 September 2001 fanatic attacks in New York and Washington D. C. The devastating effect of these twin attacks has raised global concern about the potential use of WMD by Al-Qaeda, the Islamic State of Iran and Syria (ISIS), and their affiliate groups. One major issue of great concern in recent times, apart from the propensity of the terrorist organizations to acquire WMD, is the involvement of state actors that secretly acquire or claim to have acquired them for the purposes of electricity generation. Notably, too, is the trend in modern scientific and technological improvement which has increased the nature of, and access to, WMD. This research, therefore, attempts to access the implication and impact of WMD as terrorists put them to use. The study also examines the concept of terrorism and WMD. Also examined is the general implication of the use of WMD and the challenges this might pose to the international community, considering the current trends in their acquisition by some states and non-state actors. The investigation suggests appropriate counter-measures to thwart terrorists' effort to acquire WMD. The study also adopted the qualitative approach of research to analyse the sophistication adopted by new terrorist groups particularly by the ISIS terrorist network; the al-Qaeda group and other splinter groups. Thus, historical research is most appropriate for this study, and secondary source of data was adopted as its methodology.
\end{abstract}

Keywords: weapons of mass destruction, modern terrorism, international community, intelligence community, global security, nuclear weapons

\section{Introduction}

\subsection{Introduction}

One of the biggest challenges humanity faces today is the problem of terrorism and the introduction and use of Weapons of Mass Destruction (WMD). In essence, WMD has become the issue of topical discourse in academic; within the International Intelligence Community (IIC) and in general security circles the world over. The growing concern at this time is the likelihood that virtually all known and renowned terrorist groups such as al-Qaeda, Taliban, the Islamic State of Iraq and Syria (ISIS), etc., and their affiliates and/or splinter groups may acquire WMD for the express purpose to cause huge collateral damage as evident in the Syrian sarin gas attack and other such attacks (Jaspal, 2008). Since the emergence of the al-Qaeda terrorist organization and the terrorist twin attack on the Towers of the World Trade Centre and the Pentagon, where passenger air planes were used as weapons of mass destruction to kill over 3,000 persons on September 11, 2001 (now commonly referenced as the nine-eleven event), the United States Intelligence Agency and the International Intelligence Community (IIC) are now questioning the interests and efforts of al-Qaeda, Taliban, Boko Haram, and the latest among the deadliest, the Islamic State of Iraq and Syria (ISIS), and their affiliates and splinter groups in acquiring biological, chemical, nuclear and radiological weapons (Imobighe, 2006; Reshmi, 2013). The greatest fear or threats emanating from terrorism today is the increase in the use of modern technology, including the possible adoption of cyber technology in warfare. Added to this is the involvement of state actors in financing terrorist 
organizations. So also are the activities of criminal networks in smuggling light weapons across national borders, as well as the deployment of WMD in its miniature form, to cause havoc and damages to lives and properties. The effects of chemical and biological agents are very deadly, while a single weapon like the size of an apple fruit could kill and maim thousands of people within the shortest period of time (Sekulow et al., 2014).

Analysts are agreed that WMD may not be bigger than an apple fruit size but if it explodes, it could kill an entire continent. This is evident in the Tokyo subway multiple attacks of 1995 in which the Japan-based religious movement, Aum Shinrikyo, used an odourless, colourless, and highly toxic nerve gas, sarin, in the city's subway system, to cause the death of 13 persons and caused bodily injury to over 5,500 persons. Today, the ISIS has emerged as the most ruthless and most successful of the Sunni Jihadist organization in Iraq and Syria, and its activity is so bad to the extent that other well-known radical Jihadist groups distance themselves from ISIS as they publicly condemn their actions and even attack them directly (Revaz-Beshidze, 2002; Sekulow et al., 2014).

Modern terrorist groups which include the al-Qaeda, ISIS, Taliban, al-Shabaab in Somalia, and Boko Haram in the West African sub-region, and a handful others have adopted a more radical approach in carrying out unwholesome acts on their targets. Usually, they aim at soft targets that they consider as infidels of the Christian, Muslim or Jewish population who live in densely populated areas in the Middle East and other parts of the world where they operate (Adishi \& Oluka, 2018). Recently, the global spread of al-Qaeda and ISIS, and their recourse to sophisticated bombs and other WMD have attracted the attention of the U.S. Intelligence Community, the United Nations Security Council (UNSC) and, yes, the international community in general. Besides natural disasters which occasionally occur in parts of the world, these bodies consider that one of the greatest threats to humanity in our contemporary age lies in the sophistication and use of cyber technology and WMD in battle along with states' involvement in financing terrorism. At this juncture, it is pertinent to ask: what efforts have the international community made to frustrate the endeavour of terrorists in acquiring WMD and/or to combat terrorism in its entirety?

The answer to this question can be found in the series of efforts made by the United Nations (UN) in its resolutions at the UN Commission on Conventional Armament (CCA) summit. To be certain, the CCA generated the first authoritative definition on WMD in 1948. The UN Security Council established the CCA in 1947 in response to a recommendation contained in the General Assembly Resolution 41 (1) which recommended the creation of a committee and made mention of the need to eliminate or prohibit atomic and nuclear weapons and all other forms of weapons "adoptable now or in the nearest future for mass destruction" (Seth Carus, 2012). International law, as a result, bans the use of biological and chemical weapons covered by the Geneva Protocol of 1925 and the Biological Weapons Convention (BWC) of 1972. The 1972 BWC, for instance, prohibits the development, production, stockpiling, transfer and acquisition of biological weapons. As a consequence, the 1963 Partial Test Ban Treaty (PTB); the 1968 Non-Proliferation Treaty (NPT) which entered into force in 1970, and the Chemical Weapons Convention (CWC), entered into force on 12 December 1995, also prohibit the use of WMD (Revaz-Beshidze, 2002; Prawitz \& Lenard, 1996). However, the prospect of terrorist organizations to use chemical or biological weapons and other forms of sophisticated war heads against civilian population as well as on formations of military and their personnel and other security agencies have raised serious anxiety and counter terrorism concerns within the international intelligence community. Although, the use of WMD in fighting is not new, as noted earlier in this study, the possible adoption of its use by the al-Qaeda group in Iraq (AQ1), ISIS, and other terrorist organizations, or the quest to either build, acquire, or steal it, or even crash an airplane into a nuclear power plant has raised serious concerns of the trend before the intelligence community and the UN (Reshmi, 2013).

From the issues raised above, it is obvious that with the passage of time, modern scientific development and global technological expansionism may likely not limit the obstacles to the development of WMD and more sophisticated nuclear weapons if these are not properly checked on national scales and multilaterally. The availability of these materials, particularly as fissile materials, has brought much complication on the issue since state and non-state actors are now exposed to easy acquisition of the noxious and deadly materials. More complicated is the commercial use of modern technologies that have opened up new paths to the production, extraction and utilization of fissile materials able to be generated by the easy adoption of thorium-fuelled nuclear reactors (Caves \& Seth Carus, 2014). Undoubtedly, these issues are the concern of this research which needs to be addressed and hence, the need to extrapolate on the extent to which these ugly scenarios can be cushioned.

\subsection{Aims and Objectives of Study}

The aim of this study is to examine the implication of the use of WMD by terrorist organizations. While the specific objectives are to: 
(i) Look at the implications of WMD and the problems and challenges it might pose in the hands of terrorist networks, especially the al-Qaeda and ISIS;

(ii) Examine the appropriate countermeasures to adopt, to thwart the efforts of terrorists in acquiring WMD.

\subsection{Research Questions}

The following research questions are intended to give direction to this study:

(i) What will be the implication of WMD in the hands of terrorist organizations?

(ii) What are the appropriate countermeasures put in place to thwart terrorist's effort to acquire WMD?

\subsection{Methodology}

This study adopted explorative, comparative and qualitative research method to examine the implication of WMD in the hands of contemporary terrorists, particularly those of the al-Qaeda and ISIS networks, and their affiliate groups. The investigation, therefore, uses this method to look at the appropriate countermeasures adopted by the UN and the international intelligence community, to prevent the harvesting and use of WMD by these international terrorist organizations. In essence, this inquiry relied extensively on secondary data such as textbooks, newspapers, magazines, journal articles, internet materials, and the official documents of reputable international organizations.

\subsection{Terrorism: An Overview}

The term terrorism is both subjective and pejorative (Horgan, 2005). This being so, difficulties emerge in attempting to find an apt definition for the word to become classifiable as universal. The key problem with defining terrorism is that it is ultimately a moral judgement shaped by social and political contexts and so, definitions for terrorism will vary depending on these contexts (Jaspal, 2008). In other words, terrorism is a demonic and violent act against humanity which, in reality, is not a new phenomenon in any discourse (Adishi $\&$ Oluka, 2018). The term has neither a precise definition nor one that is generally accepted. However, a common understanding of terrorism will be too vague, too broad or too simplistic. Terrorism, therefore, is the use of violence and threats to intimidate or coerce, especially for political purposes; or, the state of fear and submission produced by terrorism or terrorization (Aderonke, 2015). Terrorism has for a long time been categorized into two: Traditional and Revolutionary terrorism. The former is identified as state terrorism, while the later developed from protest against political and social injustice, and operate as a supplement to insurgency and rebellion in attempt to win freedom or to bring about political and social change or as a counter response to state terrorism or oppression (Jaspal, 2008).

Contemporary discourse on terrorism still cannot find a consensus definition of the concept. This is attributed to the problem of differentiating the act of guerrilla warfare, serial killing, genocide, etc., from terrorism as it were. In this perspective, those who have sympathy for the victims of terror attack have a negative, inhumane and untoward feeling and description of the concept. Those who believe in terrorist ideology and causes see terrorism as the act of liberation, and as such they see the operators of terror campaign as freedom fighters. This has made it difficult to derive a consensus definition of the concept (Aderonke, 2015). To this end, Spencer (2006) contends that the term "freedom fighter" is used as a moral judgement when classifying the act of terrorism. Terrorists have always claimed to be freedom fighters, fighting against dictators and oppression (Pienner, 2007). The phrase “one man's terrorist is another man's freedom fighter" was coined as a result of the problem of having a consensus definition. For example, despite the world-wide condemnation of terrorist attacks, the act of terrorism is still being supported and celebrated by some elements in virtually everywhere (Jaspal, 2008).

According to the Encyclopaedia Britannica (2006), terrorism is the systematic use of terror such as bombings, killings and kidnappings as a means of forcing some political objectives. The Oxford English Dictionary defines terrorist as a person who uses or favours violent and intimidating methods of coercing a government or a community for political gains. The US Department of Defence (DOD) in 2004 defines terrorism as a "calculated use of unlawful violence or threat to inculcate fear intended to coerce or to intimidate governments or societies in the pursuit of goals that are often political, religious and/or ideological". In essence, terrorism appears to be an act which is intended to intimidate or coerce a civilian population; influence the policy of a government by intimidation or coercion; or affect the conduct of government by mass destruction, assassination, kidnapping or abducting unsuspecting citizens. And, may transcend national boundaries in terms of the means by which they are accomplished; the persons they appear or intended to intimidate or coerce; or the locale in which their perpetrators operate or seek asylum (FBI, 2006 cited in Adishi \& Oluka, 2018).

The US Army Training and Doctrine Command (2007) defined terrorism as a special type of violence that is 
directed towards civilians, government officials, institutions, companies, politicians and infrastructure. Terrorism is understood as those acts of violence which spread terror among civilians and the civil population, and is also described as an uncivilized way in which some social actors advance their irrational goals (Saqib, 2015). According to the view of social constructionist, the language of terrorism is often used to construct evil, and the word terrorism is constructionism in nature (Jackson, 2007). In the same manner, Adeyemo (2012) likened terrorism to genocide. He sees terrorism as a deliberate and systematic destruction in whole or in part, of an ethnic, racial, religious or national group. It is the illegitimate use of force to achieve a political objective when innocent people are targeted. It is the use of violence; a method of combat or strategy to achieve certain targets (Laquer, 1979; Laquer, 1987). It is against this background that Israel (2014) held that terrorism is a contemporary name given to the modern permutation of warfare purposely carried out against unsuspecting civilian population with the aim of destroying the will of those whom they target, to either support their own leaders or those policies which the terrorists find objectionable.

\subsection{Concept of Weapons of Mass Destruction (WMD)}

Prior to the emergence of the terrorist groups, including al-Qaeda, and the nine-eleven event, fears ignited serious concerns which questioned the likelihood of the fanatical groups to use WMD if these ever found their way into the hands of terrorists and their network groups. Theoretically, new trend in terrorist operations indicates that the use of WMD suit the terrorist's strategy. Hence, WMD could become an effective means to cause a large number of indiscriminate casualties (Jaspal, 2008). Seth Carus (2012) stated that the first known use of the term "weapon of mass destruction" was traced to the Archbishop of Canterbury, William Gordon Lang, in his December 1937 Christmas address titled "Christian Responsibility". The address was believed by some scholars to have been influenced by the widely publicized bombings of cities in Spain by the Fascists and the Japanese in China, plus the dangers of the Italian chemical attacks in Abyssinia previously in 1936 (Seth Carus, 2012).

However, the exposure of WMD to terrorist organizations will not only increase the level of destructions to be carried out by the dissenting elements but also will make the task difficult to exercise control on them or to combat the spread of their networks to the government of any state. Since WMD could be silent and appear in miniature form, any dangerous attacks could occur at any given time without people being aware that attacks have taken place until the effects are felt by the general population. The general opinion of scholars is that WMD are seen and understood as weapons capable of causing mass casualties. Majorly, WMD are nuclear armaments which have enormous destructive powers than other conventional ones. One nuclear warhead can destroy a large city like New York within a twinkle of an eye. Hundreds of warheads are estimated to have the capacity of destroying an entire nation (Morton, 2000).

According to the United States Government Interagency Domestic Terrorism Concept of Operations Plans in 2001, WMD is any device, material, or substance used massively in a manner, of any quantity or type, or under circumstances evidencing intent to cause death or serious injury to persons or a significant damage to property. The UN Committee on Conventional Armaments of 1948 categorically classified WMD to include atomic explosives, radioactive materials and lethal weapons which are so developed to have characteristics comparable in destructive effect to those of atomic bomb and other weapons that destroy in quantum a large number of people. In another perspective, NATO in 2010 classified WMD as "any weapon that is capable of high order destruction, capable of being used in such a manner as to destroy people, infrastructure or other resources on a large scale". According to the US Homeland Security Information Act 1366 of 2003, WMD refers to any explosive, chemical, radioactive, or biological agent, or any other substance or device capable of causing extensive property damage, death or serious physical injury to multiple persons in a single act or series of acts (US Homeland Security, 2003).

In a comprehensive manner, the District of Columbia D.C. Code 22-3152 of 2004 described the following items as WMD:

(a) Any destructive device that is designed, intended, or otherwise used to cause death or serious bodily injuries such as:

(i) An explosive, incendiary or poisonous gas such as bomb, sarin, ricin, anthrax, grenade, rocket, missile, mine or any device similar to any of the devices described above.

(ii) A mortar, cannon, or artillery pieces; or

(iii) Any combination of parts either designed or intended for use in converting any device described in sub paragraph. 
(b) An object similar or used to achieve the same destructive effect of any of the devices in sub paragraph (a) above.

(c) Any weapon that is designed, intended, or otherwise used to cause death or serious bodily injury through the release, dissemination, or impact of a biological dissemination, or impact of a biological agent or toxin; or poisonous chemical.

(d) Any weapon that is designed, intended, or otherwise used to cause death or serious bodily injury through the release, dissemination, or impact of radiation or radioactivity or that contains nuclear materials (District of Columbia, DC Code 22-3152, 2014).

2.

\subsection{WMD and the Terrorist Groups}

As noted earlier in this study, the use of unlawful threat or violent means to cause fear, and to coerce and intimidate individuals, domestic governments and the international community in the pursuit of the goals that are often political, religious or ideological is not very recent. But the recent and regrettable interest which the terrorist groups have shown in acquiring WMD and possibly use them to cause casualties is now a source of huge concern. Added to this is the proliferation of nuclear warheads produced by state actors like North Korea, Russia and Iran which has become a perturbing trend at this time. From 2006 to 2007, the al-Qaeda group in Iraq made use of chlorine tanks with high explosives to cause havoc. Between 2012 and 2013, Syria was suspected to have employed small-scale chemical weapons (CW) against rebels and the civilian population in her territory on several occasions. In the August of 2013 alone, the Syrian regime used chemical weapons against the people of Ghouta village in which over 1,500 people were killed. In Afghanistan, the terrorists had chemical agents mixed with pesticide which was used as a weapon against pupils in girls' schools, though this incident recorded limited damages. Notably, also, are the recent self-proclaimed acquisition of nuclear weapon by North Korea, and the three-time test of these weapons by the country. As well, the suspected pursuit of nuclear weapons by North Korea and its refusal to adhere to the UN Security Council resolution for the suspension of uranium enrichment has also attracted international disquiet (Caves \& Seth Carus, 2014; Hilper \& Oliver, 2018). Not even in the initial Singapore summit of 21st June 2018 could President Donald Trump of the United States of America wholly dissuade his North Korean counterpart, Kim Jong Un, from continuing with the proliferation of nuclear warhead programmes (Hilper \& Oliver, 2018, p. 7).

Again, in recent times, another matter of growing concern is the ever-increasing threat of cyber attack carried out by organized criminal groups and international terrorists that could hack into state protected nuclear facilities and disable or detonate them, or even jam the radar and disorganize the communication system, to sabotage the entire system and stop them from functioning and perhaps, to cause harmful explosion to humans (Futter, 2015). Furthermore, the growing computerization, digitalization and complexity of nuclear operations and infrastructure by state actors could possibly raise the risk of nuclear accidents and create new vulnerability and access to terrorist groups as WMD (Ross, 2008). According to Futter (2016), one of the greatest challenges facing cyber technology is the bugs that are mostly contained in sophisticated and complex software and the coding systems, such as computer based systems, especially those that rely on complex codes. Indeed, it is not very easy to hack into these weapons' system software but system errors could make the software vulnerable for terrorists to hack into, and this could cause interference, disruption and damages to the critical nuclear facilities. The consequences of the terrorists hacking into the systems software cannot be overemphasized (Futter, 2016, p. 8).

Since the 1980s, terrorists have been acquiring crude chemical and biological agents as they have always threatened and plotted to use these to cause death and physical or psychological hurt or damage to individuals or groups of individuals, as well as to damage properties. In 1987, a religious cult group, Rajneeshees, in an attempt to obstruct voters turnout in a local election, clandestinely contaminated salad with salmonella (a bacteria that is sometimes used to make people sick) in a restaurant in Oregon in which over 751 people were victims (Jaspal, 2008; Caves \& Seth Carus, 2014). This incident, according to Revaz-Beshidze (2002), is a significant example of the use of biological weapon to either disseminate pathogenic organisms or biologically produced toxins to cause illness or death in human, animal or plant populations. In Northern Sri Lanka, the Liberation Tigers of Tamil Eelam (LTTE) attacked a Sri Lanka Armed Forces (SLAF) Base with chlorine gas, injuring more than sixty military personnel in 1990. In March 1995, Aum Shinrikyo, a notorious Japanese religious cult attacked the Tokyo subway with liquid Sarin. Unaware of the toxic chemical weapon's threat the subway cleaning crews who were dispatched to clean the platform or the train car areas became casualties to its attack (US Army TRADOC G2, 2007; Jaspal, 2008).

There was also the bombing of the Murrah Federal Building in Oklahoma, U.S.A. This incident revealed the 
American right-wing militant extremism and it became comparable with the Tokyo subway attack of 1995. On 18 October 2007, a similar attack occurred in Karachi, Pakistan in which over 150 people were killed (Morgan, 2004; Jaspal, 2008). According to Gurr and Cole (2000), anthrax attacks were initiated in the U.S.A. and it is estimated that 100 kilograms of anthrax could kill up to three million people when dispersed under optimal conditions. This was evident in the 2001 anthrax attack which resulted to over 20 infections and several deaths. On 6 April 2007, a suicide bomber targeting a police station exploded his truck loaded with chlorine gas in a residential area thereby killing 27 people in Ramadi, Iraq. Undeniably, this form of attacks has been carried out on several occasions and in several locations in Nigeria by the self-styled Boko Haram Islamic radicals in recent time. In the month of March 2007, a month before the Ramadi attack, 350 civilians were hospitalized after three chlorine bombs exploded near Ramadi (Gurr \& Cole, 2000; US Army TRADOC G2, 2007).

Although the Osama bin Laden al-Qaeda terrorist network typifies modern terrorism in activity and function, however, the activities of its affiliates like the Boko Haram, in the Lake Chad Basin; the ISIS in Syria, and other smaller splinter groups, have taken over on the international scene. The splinter groups in their domains carry out several attacks on their unsuspecting victims, using dangerous weapons, particularly in the Middle East and in Africa. The implication here is that modern terrorist organizations like the al-Qaeda in the Islamic Maghreb (AQIM); Harakat Aij-Shabaab Mujahhadeen (al-Shabaab) in Somalia; Jamaratu Ahlis Sunna Lidda Awati Wal-Jihad (Boko Haram) in North-East Nigeria (or the Lake Chad Region); Al-Ittihad al Islami (AIAI) domesticated in the horn of Africa; and the ISIS in the Middle East; all or any of these groups could possibly acquire WMD in several ways. It is no longer strange, consequently, to believe that the components and technical know-how of the WMD are available in black markets across the world, compared to the availability of nuclear weapons since the materials and tools required to create biological warfare agents are easily accessible and cheap to acquire (Morgan, 2004).

It is imperative at this point to re-emphasize the point that chemical and biological terrorism and welfare are not new. This is evident in the hundreds of acts that were referred to as acts of chemical and biological terrorism. In 1915, an American physician established a small but very effective biological agent production facility in his home. He produced an estimated litre of liquid biological agents using cultures of bacillus anthraces (anthrax) and pseudomonas mallei supplied by the Imperial German Government. The liquid and a simple inoculation device were reportedly given to Baltimore dockworkers that used the biological weapon to infect over 3,000 horses, mules and cattle destined for use by the Allied Forces in Europe during the First World War. In 1978, a Palestinian group injected a good quantity of Jaffa oranges with Sodium Cyanide which seriously damaged Israeli citrus fruit export (Revaz-Beshidze, 2005).

Reshmi (2013) has also observed that the threat of WMD and terrorism is "no longer a hypothetical worry but is now on-going in our modern age". The most disturbing of all is the danger of nuclear terrorism or the use of WMD which is likely to increase if there is global absence of comprehensive implementation of policy and the resolutions on non-proliferation of WMD. To re-emphasize this, Rashmi pointed out that the nine-eleven attacks in the United States is an indication that the al-Qaeda and ISIS have no limit and constraint to WMD. To him, they operate with all seriousness and employ any crude method to unleash catastrophe on target enemies whom they consider to be infidels. The implication here is that modern day terrorists, in their form of terror campaign, are ultimately more destructive and violent in both perspective and method of practice. This is evident in their mode of operation which often includes suicide bombing, abduction, kidnapping for ransom, and the public displace of video clips showing captured victims who are traumatized, and such other inhuman acts as outright decapitation of captives, etc. In concrete terms, terrorist groups have demonstrated the commitment to buy, steal or construct WMD as evident in the 1998 declaration made by Osama bin Laden. In the declaration, bin Laden proclaimed that it was a mandatory religious duty to acquire WMD which must be used to establish Islamic caliphates and to defend Muslim communities across the world (Mowatt-Larssen, 2010).

The above is a clear indication that al-Qaeda, ISIS, and the host of other fanatical groups are bent on acquiring the deadly and destructive materials. It is also no longer difficult to believe that most of the terrorist organizations are motivated by some recalcitrant state-actors or wealthy and dissident individuals who are exposed to the sources and availability of WMD. To this effect, Reshmi (2013) identified states' assistance as one of the major drivers which propel most of the terrorist organizations to seek for weapons of catastrophic magnitude to cause huge collateral damages. This means that a terrorist group with the inclination for acquiring WMD and has a state's support will definitely have better access to funding, sophisticated weaponry, and technical and logistic support. There is the likelihood for terrorist organizations with such support from the state to possess a higher level of resources and technical expertise than it would have ordinarily possessed. This much is evident in the activities of al-Qaeda and ISIS (Rashmi, 2013). 
However, building and manufacturing nuclear WMD requires availability of sources of knowledge and technical know-how which coincidentally exists everywhere particularly in the Western World. The Western sphere of influence in the area of science and research, which is accessible in the internet and in Ph.D research theses and declassified documents accessible in academic libraries and the public, made it possible for terrorists to have access to materials and documents on WMD (Reshmi, 2013). Moreover, materials not available in the open market of the Less Developed Countries (LDCs) which are often prone to terrorist attacks, are readily available through the integrations of these countries to the global economy which also facilitate increased commerce that incidentally provides opportunities for terrorists to transport and take delivery of these WMD materials and devices mainly mixed illegally with legitimate cargos. This has made it delicate and difficult for the international intelligence community and national governments to cope with modern state sponsored terrorism.

This was complimented by the United States Government declaration that some states like Cuba, Iran, North Korea, Libya and Syria were at a time sponsoring terrorism. And recently, Sudan and Afghanistan were also fingered among the states that were sponsoring terrorism. Iran was said to have funded training camps in Sudan. Iran and Syria were also accused of supporting the Palestinian Islamic Jihad. The U.S government also has identified al-Qaeda, ISIS and their affiliate groups as the most dangerous threat to the international community who are most likely to use WMD in targeted attacks on the rest of the world and on the United States in particular. In a January 2007 annual assessment report of worldwide threats, a US Federal Bureau of Investigation (FBI) states that if terrorist organizations can obtain some form of chemical, biological, radiological, or nuclear materials, they are liable to use them to unleash threat and destroy the face of the earth. The researchers, therefore, are optimistic that al-Qaeda, the Islamic State (ISIS), Boko Haram and their splinter groups in Africa, Arab nations, and other parts of the world will likely pursue acquisition of WMD if effective multilateral agreement is not reached. Although the terror groups have often used conventional explosive weapons in their attacks, they may also be willing to use WMD weapons on a large scale. The consequences of this may lead to more suicidal attacks on targeted areas (FBI, 2007).

As Morgan (2004) puts it, modern terrorist groups are the most dangerous threats to the international community. They are the potential users of WMD, who may delighted to use same on targeted areas in the US and other parts of the world. Contemporary history has shown that the ISIS Jihadist network is the most apocalyptic group in the world today. It emerged from the al-Qaeda and was initially known as al-Qaeda in Iraq (AQI) but after the al-Qaeda rejected AQI because of its tactics which was considered too brutal, AQI metamorphosed into the Islamic State of Iraq and Syria (ISIS). Its major targets are Christians and Jews in the Middle East. It also targeted Yazidi and Shiite Muslims who do not aligned with its Jihadist form of Sunni Islam. It also targets the Alawites (an obscure Islamic sect) (Sekulow et al., 2014). By all standards, in comparing al-Qaeda and ISIS, it is obvious that the ISIS is more brutal. Members of the group are so brutal that the al-Qaeda organization tried to persuade the ISIS to change its tactics. In fact, ISIS is regarded as the richest terrorist group in the world today since it has wider links with some state actors and controls more firepower and territory than any Jihadist organization that ever exists. It was reported that ISIS seized over 40 kilogramme of radioactive uranium in Iraq thereby raising fears that it could construct a dirty bomb which is capable of dispersing deadly radiation in the atmosphere. This is capable of rendering entire affected areas uninhabitable, and could make people ill within the radius or even kill (Coghlain \& Hayne, 2014).

According to Michael and Hassan (2015), ISIS is actually the latest front in "a bloody culmination of a long-running dispute within the ranks of international Jihadism". To them ISIS is not just a terrorist organization; it is also a mafia adept at exploiting decade-old transnational grey markets for oil and arms trafficking. Furthermore, they consider ISIS as a sophisticated intelligence-gathering apparatus which infiltrates rival organizations and silently recruits their members. ISIS is equally known for its notorieties: killings, tortures, bombings and beheadings of its Western hostages which began with an American Journalist, James Foley (Michael \& Hassan, 2015). This incident has raised anxiety and counter-terrorism concerns to unprecedented heights within the military and intelligence community, and in the mass-media. Such and such would be the implications of leaving WMD in the hands of modern day terrorists like the al-Qaeda, ISIS, Taliban, Boko Haram, and their splinter groups across the world.

\subsubsection{Measures to Prevent Terrorist Efforts in Acquiring WMD}

The nuclear, biological and chemical (NBC) weapons of warfare have been the focus of intense international disarmament negotiations since the 1920s. In 1925, there was the Geneva Protocol, and the Nuclear Non-Proliferation Treaty of 1969, the Biological and Toxin Weapon Convention of 1972, and the Chemical Weapons Convention of 1993. The Geneva Protocol established a universal standard against the first use of chemical and biological weapons (CBW), while the 1972 Biological Weapons Convention (BWC) prohibits the 
development, production, stockpiling, transfer and acquisition of biological weapons (see Revaz-Beshidze, 2002; Seth Carus, 2012).

Apparently, the terminology, Weapons of Mass Destruction, was first included in the UN General Assembly Resolution of January 24, 1946 which established a commission to deal with the problem raised by the discovery of atomic energy and to suggest specific ways of eliminating atomic weapons and other weapons that can possibly cause enormous damage and destructions. Apart from the 1946 Resolution 1, Subsection (1) passed by the UN General Assembly, several measures were also put in place by the international community to run counter to insurgency and terrorism. For example, on 28 April 2004, the UN Security Council passed a unanimous resolution (Resolution 1530) calling on states to refrain from supporting non-state actors like the al-Qaeda, ISIS, Taliban, and other affiliate terrorist groups in pursuit of WMD and to adopt and enforce domestic laws and control towards WMD. This resolution re-emphasized the approach previously taken under UNSCR 1373 of 2011 (see UN Security Council Resolution 1540, 2004: UNSCR 1373, 2011).

On 15 November 1945, there was also the joint declaration for a collective control of atomic energy and the urgent calls for a UN Commission to identify ways to control atomic weaponry and other nuclear warheads by frontline world leaders notably from the USA, the UK and Canada (Seth-Carus, 2012, p. 2). On 8 September 2006, the UN General Assembly under resolution 1673 adopted what is today known as "Global Counter-Terrorism Strategy" which is a unique instrument adopted to enhance national, regional and global efforts, to counter all forms of terrorism. Essentially, this was to be reviewed every two years, thereby making it a vital document to guide member states' counter-terrorism priorities. It also addresses the conditions conducive for the spread of terrorism; measures to prevent and combat terrorism; measures to build states' capacity to prevent and combat all forms of terrorism and to strengthen the system in that regard. Similarly, the Global Counter-Terrorism Strategy also put in place measures to ensure respect for human rights for all and the rule of law as the fundamental basis for the fight against all forms of terrorism including the use of WMD (Global Counter-Terrorism Strategy, 2006; Kelsey, 2017).

These issues were reviewed in 2006 under resolution 1673 as it was again reviewed after another two years under resolution 1810 in 2008 and yet again in 2011 under resolution 1977. These resolutions were also taken to reaffirm the UN Security Council's commitment to Resolution 1540. The 2016 Summit, thus, marked the $10^{\text {th }}$ anniversary of the UN Global Counter-Terrorism Strategy (Kelsey, 2017). On 15 January 2016, the UN Secretary General, in attempt to reaffirm resolution 1540 and also to combat some recent threats posed by the terrorist organizations, presented a "Plan of Action to Prevent Violent Extremism" to the General Assembly. On 12 February 2016, the General Assembly adopted a resolution that welcomes the initiative by the Secretary General. There was also the Geneva Conference on Preventing Violent Extremism on the $7^{\text {th }}$ and $8^{\text {th }}$ of April 2016 at the UN office, for the express purpose to provide the opportunity for the international community, to share experiences and good practices in addressing the threats of violent extremism and to re-emphasize the Secretary General's plan of action. And, in the December of 2016, the UN Security Council adopted Resolution 2325 which encouraged states to strengthen their implementation of Resolution 1540 (UN Global Counter-Terrorism Strategy, 2006; Kelsey, 2017).

In September 2004, Pakistani Parliament, in response to the UN Security Council Resolution, enacted the Export Control on Goods, Technologies, Material and Equipment Related to Nuclear and Biological Weapons and their Delivery System Act to strengthen controls on the export of sensitive technologies particularly those related to nuclear and biological weapons and their means of delivery. In April 2007, the government in Pakistan also established a Strategic Export Control Division (SECDIV) in the Ministry of Foreign Affairs purposely to monitor and implement the Export Control Act of 2004. On 13 December 2007, there was another attempt to augment the security of Pakistan's nuclear infrastructure under a National Command Authority (NCA) Ordinance promulgated under President Pervez Musharaf. This was meant to secure Pakistan assets from terrorists (Jaspal, 2008).

Realistically, it is not easy to completely prevent WMD terrorism because of its complex nature and the involvement of state actors and organized criminal gangs. In short, preventing terrorist organizations from acquiring WMD materials is a difficult task to accomplish because of the availability of the materials in black markets as earlier noted in the cause of this study. Although states like the US has had to make concerted efforts to, at least, eliminate the proliferation of WMD in three treaties which place limitations on these weapons rather than on each of nuclear, chemical, or biological weapons. These treaties are the 1967 Outer Space Treaty, the 1972 Seabed Treaty, and the 1991 Strategic Arms Reduction Treaty. In 1967, there was a draft treaty on Principle Governing the Activities of States in the Exploration and use of Outer Space, including the moon and other Celestial Bodies, also known as the Outer Space Treaty that was intended to prohibits placement of WMD in 
outer space particularly in Article IV of the treaty. In 1972, the United States and Soviet Union negotiated another treaty that also placed specific restrictions on WMD. The Treaty otherwise known as the Treaty on the Prohibition of the Emplacement of Nuclear Weapons and other Weapons of Mass Destruction on the Sea-bed and the Ocean floor and in the subsoil did impose restrictions on the geographic placement of WMD. This treaty is commonly known as the Seabed Treaty (Seth Carus, 2012).

India has also taken steps to combat the illicit proliferation of WMD by cooperating with the international community to promote and advance the goals of non-proliferation and international security. India, according to Reshmi (2013), recognizes the importance of handling its nuclear materials and technology right from its production stage to its usage, as well as its safe and secured disposition to the public and terrorist organization which is still enforced in recent time. To this end, India joined the Convention on the Physical Protection of Nuclear Material (CPPNM) and the Convention on Nuclear Safety (CNS) directed towards the protection and safeguard of nuclear facilities. In November 2004, India submitted its first report on measures it had taken to comply with United Nation Security Council Resolution (UNSCR) 1540. It also played exemplary role by promulgating an ordinance to amend the Unlawful Activities Prevention Act of 1967 which prescribed punishment for any un-authorized possession or use of any bomb, dynamite, or hazardous explosive substance of warfare in 2006. As a responsible state, it also refrains from any illicit nuclear activity involving or aiding and abetting terrorist acts. This was clearly demonstrated in its Weapons of Mass Destruction and their Delivery Systems Prohibitions of Unlawful Activities Act of 2005 which also criminalized any transfer of WMD, missiles, etc., for use in terrorist acts particularly in Sections 8 \& 9 (Reshmi, 2013).

With the increasing wave of Islamic Jihadist movements, most states in the Middle East, Africa and the Western world have consistently strengthened and tightened their domestic security apparatuses and legislation to be able to combat terrorism. Recognizing the threat posed by terrorism and the use of WMD and to prevent the threats of possession and potential use of WMD by states and non-state actors, Pakistan expressed her commitment and determination to several international treaties on non-proliferation instruments. These include the Nuclear Safety Convention; Convention on Physical Protection of Nuclear Material (CPPNM); Chemical Weapons Convention (CWC); Biological and Toxins Weapons Convention (BWC); International Conventions against Terrorism and Global Initiative to Combat Nuclear Terrorism. It has also continued to review and tighten its controls over sensitive technology and nuclear materials, and continued to work with the UN Security Council Resolution (UNSCR) Committee and other partners at the international, regional and sub-regional levels, to implement Resolution 1540 (Reshmi, 2013). In other words, UN Security Council Resolution 1540 of April 2004 represents a new approach to the prevention of the use of WMD by terrorists. It established a mandatory requirement for all states to refrain from providing any form of support to non-state actors in obtaining WMD. It also mandates states to adopt domestic legislation, to implement this obligation and also requires them to establish national controls to prevent the proliferation of WMD and their means of delivery (UN Security Council Resolution 1540, 2004.) In 2003, the European Union (EU) adopted a strategy against the proliferation of weapons of mass destruction. This was purposely designed to convince member nations that they do not need the WMD and to prevent terrorism in any form. In Latin America, the South Pacific, Africa and South-East Asia, regional measures which included treaties establishing nuclear-weapon-free zones (NWFZ) were initiated and states in these regions agreed to forgo the proliferation of WMD. This was also emphasized in the 1967 Tlatelolco treaty which created new avenue for states in Latin America and the Caribbean to establish nuclear-weapon free zones. States in the Middle East also adopted and established WMD-free zone but the persistent conflict in the region made it impossible to prevent terrorism by the use of WMD (US Department of State Country Reports on Terrorism, 2008).

According to James, Jason \& Alistair (2010), the Dakar Declaration against Terrorism adopted in October 2001 by the African Summit Against Terrorism, and the 2002 Plan of Action of the African Union for the Prevention and Combating of terrorism are some of the significant efforts made to strengthen the capacity of West African States in addressing WMD for terrorism purposes; and the recruitment, financing, movement, training, propaganda, and operations of terrorist groups in the West African Sub region. Since the year 2001, the United States (US) has been in the fore front in assisting North African States in combating the threat of proliferation of WMD and the spread of Islamic extremism. The EU and France in particular are historically the main external partners of the North African sub region before the United States dramatically increased its engagement with the states in the Maghreb and Sahel, in the area of counterterrorism and other related areas including the non-proliferation WMD. In short, all the countries in the sub region including Algeria and Libya have benefitted from counter terrorism capacity-building assistance through the state department's antiterrorism assistance, terrorism interdiction, and other related programmes (Berkouk, 2009; US Department of State, 2010; James et al., 
2010).

Through the Trans-Sahara Counterterrorism Partnership (TSCTP), the US has also sought to improve its cooperation with the Maghreb countries by strengthening the region's counterterrorism capabilities; enhancement and institutionalization of cooperation among the security forces in the sub region; the promotion of democratic reinforcement of bilateral military relations with the United States; and most importantly, the non-proliferation of Weapons of Mass Destruction (US. Department of State Country Reports on Terrorism, 2008).

Some States in Africa under the umbrella of the African Union (AU) adopted a broad-based continental framework to combat terrorism and the proliferation of WMD. This is evident in the $2004 \mathrm{AU}$ establishment of the African Centre for the Study and Research on Terrorism (ACSRT) as a technical arm on matters related to terrorism. The ACSRT is charged with a number of functions aimed at enhancing counterterrorism capacities and cooperation among its member states particularly on WMD (Rosand, Alistair, \& Jason, 2008). Efforts were also made to strengthen counterterrorism mechanisms and to control the spread of other forms of transnational crime including money laundering, drug trafficking, weapon smuggling and WMD in recent time. This was demonstrated in the April 12, 2018 address of the UN Secretary-General, Antonio Guterres, in a UN Youth Forum. At the forum, Guterres reiterated the pertinence of empowering youths globally so as to combat terrorism. To him, "young people are prime targets of extremist recruiters but they can also play leadership roles in fighting terrorism and at the same time provide greater opportunities for all" (UN News, 2018).

\subsection{Effects of Terrorism}

From the plethora of literature above, it is true that biological and chemical agents, when found in the possession of non-state actors or with terrorist groups, can be used indiscriminately to cause damage, assassination, and as foot and mouth disease. Some are capable of causing death, serious physical or mental damage or injury to someone in contact with them (Caves \& Seth Carus, 2014). Simply stated, WMDs are devices or tools purposely designed and intended to cause death, physical or mental damage or injury, to targeted individuals or group of individuals; or properties, through their dissemination or release. WMD include atomic weapons, radioactive materials, and lethal chemical or biological weapons. Grenade, rockets, missile technology and delivery systems such as aircraft and ballistic missiles also belong to the categories of these weapons (Laura, 2014).

The economic effect of having WMD can equally be devastating. These materials in the hands of terrorists can have devastating effects. The economic consequence of allowing WMD in the hands of terrorists could be more colossal. This is so because money that is meant for the development of the state will be diverted to fight terrorism and rebuild infrastructure, as well as used for relief services during and after terror attacks. While death, injuries and physical destructions are the most visible effects of terrorist attacks, it is given that fear, violence, uncertainty and indirect effects will become harmful to the economy in the long run. The effects of terrorism are contagious in a global village where there is interconnectedness of activities including trade routes. The use of WMD generally can have political and military effects (Caves \& Seth Carus, 2014). Terrorism also has significant fiscal effects, and both direct and indirect effects on growth. A policy issue of the defence against terror requires awareness of the motivations and objectives of terrorism. The policy can result in changed perceptions thereby affecting the majority in the way they execute their functions. Terrorism is deemed to be a usurper of human security such that there is chaos among the civilians after each substantial terror attack.

\section{Recommendations}

To prevent terrorist organizations from using WMD, the study provides the following recommendations:

(i) Regional and sub-regional counterterrorism strategies should be encouraged and strengthened.

(ii) Uniform standard of counterterrorism measures should be critically enforced by nations irrespective of the regional affiliation and patterns of attack or tactics adopted by the terrorists.

(iii) A review of some of the already existing treaty agreements on counterterrorism strategies should be encouraged to accommodate the modern trends adopted by terrorist organizations.

(iv) States-sponsored terror networks should be sanctioned and severely dealt with.

(v) UN General Assembly Resolution 1540 of 2004 and other sundry resolution of the Security Council should be strictly enforced by the UNSC particularly on member nations.

(vi) Further steps should be taken by state actors like Iran Iraq Afghanistan and Syria, and non-state actors such as the United States, Russia, China, India, Pakistan, African Union, and the European Union to 
combat the illicit proliferation of WMD and encourage other international communities to promote and advance the goal of non-proliferation of WMD and international security.

(vii) State or military actions should be taken against some of these terrorist organizations.

(viii) Creating an enabling environment for economic, social, political and religious issues to strive without infringement against human rights and democratic ethos.

(ix) Policy implementation should be a priority to governments around the world.

\section{Conclusion}

This research which examined the use of WMD and modern terrorism, and its implication to global security revealed that there is paradigm shift from the use of conventional weapons of warfare to the use of unconventional weapons by modern day terrorists. The consequence of this is the security challenges witnessed in recent times by the international community and in which the nations of the Middle East, Africa, and United States are the most affected. The study revealed among others that the use of unconventional weapons was rare and uncommon before the twin terrorist attacks on the United States in 2001 by the al-Qaeda terrorist network. The proliferation of nuclear weapons by recalcitrant states and state-sponsored radicals have been identified as one of the major threats to the UN Security Council and other relevant regional and sub-regional agencies such as the Trans-Sahara Counterterrorism Partnership (TSCTP), Africa Centre for the Study and Research on Terrorism (ACSRT) among others.

Essentially, too, are several non-proliferation conventions and resolutions passed by a group of sovereign nations and the UN General Assembly through its Security Council to eliminate atomic weapons and other weapons adaptable for mass destruction. An example is the April 28, 2004 UNSC Resolution calling on states to refrain from supporting non-state actors like the al-Qaeda, ISIL, Taliban, Boko Haram and other affiliate terrorist groups in pursuit of WMD, and to pass legislations on domestic laws, to control WMD in their respective states. The 1925 Geneva Convention, the Nuclear Non-proliferation Treaty of 1969, the Biological and Toxin Weapon Convention of 1972, and the Chemical Weapons Convention of 1993 are also essential. The study concludes that modern terrorism should be prevented from the use of WMD by strict adherence to the provisions of the UN resolutions and conventions, and other regional and sub-regional counter terrorism measures which have been put in place by relevant agencies and research findings.

\section{References}

A Military Guide to Terrorism in the Twenty-first century, US Army Training and Doctrine Command (p. 3). (2004, October 12).

Aderonke, M. (2015). Terrorism and Counter-terrorism in Contemporary Nigeria: Understanding the Emerging Trend. Journal of Policy and Development Studies, 9(4), 129.

Adeyemo, D. (2012). Fighting Terrorism in Nigeria. The Nations Newspaper.1 August, 2012. In Aderonke, M. (2015). "Terrorism and Counter- terrorism in Contemporary Nigeria: Understanding the emerging Trends". Journal of Policy and Development Studies, 9.

Adishi, E., \& Oluka, N. L. (2018). Domestic Counter-Terrorism Mechanism and Human Right Abuse in Nigeria: The North-East Experience. Journal of Political Science and Leadership Research (JPSLR), 4(2).

Berkouk, M. (2009). US, Algerian Security Cooperation and the War on Terror. Carnegie Endowment for $\begin{array}{lllll}\text { International } & \text { Peace, } & \text { June } & \text { Retrieved }\end{array}$ https://www.cargegieendowment.org/publications/index.cfm?fa

Caves, J. P., \& Seth Carus, W. (2014). The Future of Weapons of Mass Destruction: Their Nature and Role in 2030. Center for the Study of Weapons of Mass Destruction Occasional Paper No. 10: National Defence University Press, Washington, D. C.

CIA World Fact book-Oman's Economy. Retrieved from http://www.cia.gov/library/publications/theworld-factbook/geo/mu.html\#ECON

Coghlan, T., \& Hayne, D. (2014, July 11). Fear of Dirty Bomb as ISIS Rebels Seize Radioactive Uranium in Iraq. Australian. In J. Sekulow et al. (Eds.), Rise of ISIS: A Threat We Can't Ignore'New York: Howard Books.

District of Columbia D. C. Code 22-3152. (2004).

Federal Bureau of Investigation (FBI). (2006). Terror 2000. Retrieved from http://www.fbi.gove/puplication/terror2000-2001htm 
Futter, A. (2015, February). Hacking the Bomb: Nuclear Weapons in the Cyber Age. Draft working paper for ISA Annual Conference, New Orleans.

Futter, A. (2016, July). Cyber Threats and Nuclear Weapons: New Questions for Command and Control, Security and Strategy. Royal United Services Institute, RUSI Occasional Paper.

Greg, B. (2015, January 24.). What's happening in the Middle East and why it matters. CNN. Retrieved from http://www.cnn.com/2015/01/22/yemen-violence or http://en.wikipedia'org/wiki/Free-Market

Gurr, N., \& Cole, B. (2000). The New Face of Terrorism: Threats from Weapons of Mass Destruction. London: I. B. Tauris Publishers. In Z. N. Jaspal (Ed.), WMD Terrorism and Pakistan; Counterterrorism. Defence against Terrorism Review, 1(2).

Hilper, H. G., \& Oliver, M. (2018, December 12). Facets of the North Korea Conflict. German Institute for International and Security Affairs. SWP Research Paper. Retrieved from http://bt-ly/SWP18DNK-Korean-Peninsula

Horgan, J. (2005). Terrorism and Political Violence: The Psychology of Terrorism. New York: Rout Ledge.

http://www.cnn.com/2014/04/11/opinion-boston-bombing-awlaki-jihsdists/.

Israel, A. O. (2014). Africa and the Resurgence of Terrorism. Revisiting and Social Sciences, 2(2), 1-2.

Jackson, R. (2007). Constructing Enemies: Islamic Terrorism in Political and Academic Discourse. Government and Opposition, 42(3). https://doi.org/10.1111/j.1477-7053.2007.00229.x

James, C., Jason, I., \& Alistair, M. (2010). Implementing the UN Global Counter-Terrorism Strategy in North Africa. Center on Global Counterterrorism Cooperation. New York.

Jason, I., James, C., \& Alistair, M. (2015, September). Implementing the UN Global Counter-Terrorism Strategy in West Africa on Global Counterterrorism Cooperation.

Jaspal, Z. N. (2008). WMD, Terrorism and Pakistan: Counterterrorism. Defence against Terrorism Review, 1(2), 103-118.

Laquer, W. (1979). Terrorism: A Penetrating Study of the Origins, Ideology and Sociology of Terrorism. New York: Little-Brown Publishers.

Laquer, W. (1987). The age of terrorism (2nd ed., pp. 142-150). Boston: U.S.A: Little and Brown Publishers.

Laura, R. (2014). Weapons of Mass Destruction. Hampshire College. Retrieved from https://en.m.wikipedia.org/wiki/Weapon-of-mass-destruction

Michael, W., \& Hassan, H. (2015). ISIS: Inside the Army of Terror. New York: Regan Arts.

Morgan, J. M. (2004). Special Reports on the Origins of the New Terrorism. The Commander of the Headquarters and Headquarters Operations Company (HHOC) $125^{\mathrm{TH}}$ Military Intelligence Battalion. Schofield Barracks, Hawaii.

Morton, B. M. (2000). Relearning the ABCs: Terrorists and Weapons of Mass Destruction. The Non-proliferation Review/Summer.

Mowatt-Larssen, R. (2010). Al Qaeda Weapons of Mass Destruction Threat: Hype or Reality? Forward by Graham, R. Harvard Kennedy School, Belfer Center for Science and International Affairs. Retrieved from $\mathrm{http}: / /$ belfercenter.org

NATO Glossary of Terms and Definitions, AAP-6, 2010. Retrieved from http://www.nato.int/docu/stranaglaap006/aap6.htm

Pienner. (2007). International Terrorism in Africa 1990-2004: Extent and Counter-Terrorism. South Africa: University of Pretoria.

Prawitz, J., \& Leonard, J. F. (1996). A Zone Free of Weapons of Mass Destruction in the Middle East. United Nations Institute for Disarmament Research Geneva, UNIDIR/96/24. Retrieved from http://www.unidr.org>publication>pdfs

Reshmi, K. (2013). Nuclear Terrorism: The New Terror of the $21^{\text {st }}$ Century. NewDelhi. Institute for Defence Studies and Analysis (IDSA). Retrieved from http://www,idsa.in

Revaz Beshidza, G. (2002, May 26). Weapons of Mass Destruction and International Terrorism. Final Report Tbilisi. 
Rosand, E., Alistair, M., \& Jason, I. (2008). Implementing the UN Global Counterterrorism Cooperation. New York. Retrieved from http://www.globalct.org.

Ross, A. (2008). Security engineering: guide to building dependable distributed systems. Indianapolis: Wiley Publishing. Cited in Futter, A. (2015). "Hacking the Bomb: Nuclear Weapons in the Cyber Age". Draft working paper for ISA Annual Conference, New Orleans.

Saqib, J. (2015). Terrorism and Human Rights. International Islamic University, Pakistan Civil Judge/Judicial Magistrate: Sociology and Anthropology, 3(2), 104-115.

Sekulow, J., Jordan, S., Robert, W. A., \& David, F. (2014). Rise of ISIS: A Threat We Can't Ignore. New York: Howard Books.

Seth Carus, W. (2012). Defending Weapons of Mass Destruction. Center for the Study of Weapons of Mass Destruction Occasional Paper No.8. National Defence University Press. Washington, D. C.

Spencer, A. (2008). Questioning the Concept of New Terrorism. Journal of Peace, Conflict and Development, 8. Retrieved from http://www.peacestudies.journal.org.uk

Terrorism and WMD in the Contemporary Operational Environment.U.S. Army Training and Doctrine Command. TRADOC G2 Handbook No. 1.04.20 August 2007.

The Homeland Security Information Act, Act 1366 of 2003. (2003 April 15).

U.S Committee on Conventional Armaments. (1948 August).

U.S. Army Training and Doctrine Command TRADOC G2 Handbook No. 1.04.TRADOC Intelligence Support Activity TRISA-Threats Fort Leavenworth.Kansas. (2007, August 20).

U.S. Department of State, Bureau of Near Easter Affairs. (2010, March 5). Retrieved from http.//www.state.gov/r/pa/bgn/5309.htm\#relations

U.S. Department of State. Country Reports on Terrorism: U.S. Africa Command, 2008. Retrieved from $\mathrm{http}: / / \mathrm{www}$. state.gov/documents/organization/122599.pdf

U.S. Government Interagency Domestic Terrorism Concept of Operations Plan. (2001, January). B-5: www2.fbi.gov/publications/conplan/conplan.pdf.

UN General Assembly Resolution, 1(1), January 24, 1946. In Seth, C. W. (2012) Defining Weapons of Mass Destruction. Centre for the Study of Weapons of Mass Destruction Occasional Paper No.8. January, 2012, Washington, D. C: National Defence University Press.

UN Security Council Resolution 1540. (2004, April 28). Retrieved from http://www.wmdcommission.com

\section{Copyrights}

Copyright for this article is retained by the author(s), with first publication rights granted to the journal.

This is an open-access article distributed under the terms and conditions of the Creative Commons Attribution license (http://creativecommons.org/licenses/by/4.0/). 